\title{
Punishing Childhoods: Contradictions in Children's Rights and Global Governance
}

Vanessa Pupavac

School of Politics and International Relations

University of Nottingham

NG7 2RD

vanessa.pupavac@nottingham.ac.uk

A later proofed version is to be published as follows: Vanessa Pupavac (2011 forthcoming) 'Punishing Childhoods: Contradictions in Children's Rights and Global Governance.' Intervention and Statebuilding, Vol. 5, No. 3.

Earlier versions were presented at the Children's Rights Centre, Antwerp University, Belgium and the Institut Universitaire Kurt Bösch, Switzerland

\begin{abstract}
The article considers efforts to eradicate corporal punishment as an aspect of the global governance of childhood and raises problems relevant to global governance more broadly. The article analyses contradictions in children's rights advocacy between its universal human rights norms and implicit relativist development model. Children's rights research is influenced by social constructivist theories, which highlight the history of childhood and childhood norms. Earlier social constructivist studies identified the concept of childhood underpinning the Convention on the Rights of the Child (CRC) as a Western construction based on Western historical experiences, which excluded the experiences of childhood in developing countries. More recent social constructivist approaches emphasise how childhood norms are constructed and therefore can be reconstructed. The article outlines problems with attempts to globalise childhood norms without globalising material development. The article discusses the softening of discipline norms in Western societies historically. It indicates problems with children's rights advocacy seeking to eradicate the corporal punishment of children globally without globalising the material conditions, which underpin the post-industrial ideal of childhood embodied in the CRC.
\end{abstract}

\section{Righting punishing childhoods}

The UN Convention on the Rights of the Child (CRC) came into force two decades ago and provides a framework of global governance for children. The CRC - with only two non-ratifying states - the United States and Somalia - has complimented other international and regional norm-setting documents such as the Plan of Action of the 1990 World Summit for Children, and further international reports such as the UN Secretary General's end of decade review We the Children (UN, 2001) and the UN General Assembly A World Fit for Children (2002a). Additionally UNICEF's concerns are being incorporated into global governance through the internationally guided national Poverty Reduction Strategy Papers (PRSPs), which have replaced the previous structural adjustment programmes. Indeed the PRSPs are influenced by UNICEF's policies to protect children in indebted countries over two decades (UNICEF, 1987; 1999). However the Committee on the Rights of the Child and child 
advocacy NGOs want tighter integration of children's rights into the PRSPs (Committee on the Rights of the Child, 2003, para 62).

This article considers efforts to eradicate corporal punishment as an aspect of the global governance of childhood and raises problems relevant to global governance more broadly. Advocates want to embed the CRC's provisions into cultures globally to improve children's lives. Is it possible to universalise children's rights into cultural norms in different social conditions globally? I explore problems in global children's rights advocacy as it attempts to reconstruct punishing childhoods globally, highlighting the contradictions between global children rights and international development goals.

Physical punishment has long been viewed as violent assault by children's rights advocates and is a major focus of global advocacy. Campaigning organisations came together in 2001 under the Global Initiative to End All Corporal Punishment of Children, which calls for a universal legal prohibition against all forms of corporal punishment, including smacking in the home. Earlier children's rights documents do not contain specific clauses prohibiting physical punishment. For example, under Article 20 on Parental Responsibilities of the African Charter on the Rights and Welfare of the Child, parents have the duty 'to ensure that the best interests of the child are their basic concern at all times', 'to secure, within their abilities and financial capacities, conditions of living necessary to the child's development', and 'to ensure that domestic discipline is administered with humanity and in a manner consistent with the inherent dignity of the child'.

International children's rights advocates seek to extend both international and national provisions to outlaw corporal punishment globally. A number of individuals and organisations associated with the Global Initiative influenced the UN Secretary General's Study on Violence against Children (2006) and the CRC Committee's firmer stance, which supports universally outlawing corporal punishment, including in the home. The CRC Committee made a General Comment on the right of the child to protection from corporal punishment (UN CRC, 2006a). It has criticised many states over the use of corporal punishment and recommended that states take legal and other measures to eradicate corporal punishment, as this extract from its 2006 report to Benin illustrates:

The Committee recommends that the State party:

a. explicitly prohibits corporal punishment by law in the family, schools and institutions and implement existing prohibitions;

b. conduct a comprehensive study to assess the causes, nature and extent of corporal punishment as well as an evaluation of the impact of measures undertaken so far by the State party to reduce and eliminate corporal punishment;

c. introduce public education, awareness-raising and social mobilization campaigns on the harmful effects of corporal punishment with a view to changing the general attitude towards this practice and promote positive, nonviolent, participatory forms of childrearing and education; 
d. ensure that an educational programme be undertaken against corporal punishment, insisting both on the child rights $[\mathrm{sic}]$ and psychological aspects; and

e. ensure recovery and social reintegration of victims of corporal punishment (UN CRC, 2006b)

Paulo Pinheiro, the Independent Expert on the UN Study on Violence against Children, has argued, 'Hitting or smacking children is a type of violence' and 'should never be viewed as legally or culturally acceptable' (UNICEF, 2005). But corporal punishment has been culturally acceptable historically. Advocates highlight difficulties changing attitudes within states and among ordinary people, even where some national legal changes have been made under pressure from the CRC Committee and the global campaigns. Physical punishment of children has softened in Western countries, although what is deemed acceptable punishment among ordinary people may still clash with the views of children's rights advocates (Schofield, 2007). The gulf between the discipline norms espoused by global children's rights advocates and ordinary people is much wider in developing countries. The next section considers social constructivist approaches towards culture, which strongly influence childhood studies and increasingly influence children's rights studies.

\section{Constructing and reconstructing childhood}

Social constructivist theories regard the traditional protection and welfare approaches as paternalistic. They do not dispute children's need for special protection, but they emphasise the socially-constructed nature of childhood and human rights' potential to empower children (Donnelly, 2003, p.16, p. 61; Federle, 1994; Freeman, 1997, p.344; Verhellen, 1997). Legal recognition of children as distinct rights-holders is regarded as transforming attitudes towards children as well as children's views of themselves and their participation in society. Conversely international policy in the past saw legislation as only having a limited role in addressing children's plight in poor, traditional or semi-industrial societies (UNICEF 1963, p. 23).

Social constructivist studies, pioneered by Aries (1962), have analysed the historically or culturally contingent character of social organisation and norms. Earlier studies reflected social progressive theories emphasising the interrelationship between culture, law and material conditions. These linkages informed classic sociology and Marxist approaches, notwithstanding their important theoretical and political differences (Berger et al 1974, pp. 29-43, 90-105; Marx, 1990; Weber, 1954). Studies have examined both changing historical and cross-country cultural distinctions (Aries, 1963; Boyden, 1990; Burman, 1995; Cox, 1996; Verhellen, 1997) and compliment earlier anthropological studies analysing childhood in different cultures (Mead and Wolfenstein, 1955).

The CRC's preamble sets out a universal model of childhood embodying a space in which the child develops his or her personality 'in an atmosphere of happiness, love, understanding'. The ideal has been affirmed as a global goal since 1990. The UN's $A$ World Fit for Children invokes the ideal:

We adopt the Plan of Action [...] confident that together we will build a world in which all girls and boys can enjoy childhood - a time of play and learning 
in which they are loved, respected and cherished, their rights are promoted and protected, without discrimination of any kind, in which their safety and wellbeing are paramount and in which they can develop in health, peace and dignity (UN GA, 2002a, para 9).

Constructivist approaches demonstrate that a specific history informs the CRC's global model of childhood. The industrial history of European and North American societies made child labour a distinct acute social problem, but later raised family living standards allowing families to dispense with children's labour, as I discuss below. The late industrial conditions permitted childhood to be a period of education and play free from employment and other adult responsibilities (Cox, 1996; Cunningham, 1995; Hindman, 2002; Tuttle, 1999). The CRC has been criticised for codifying a Western model of childhood and excluding the experience of children in developing countries who take on adult responsibilities before their teens (Bar-On, 1996; Boyden, 1990; Burman, 1995; Lewis, 1998). Codifying a model of childhood derived from the social conditions of post-industrial societies delegitimises the childhood norms of other societies (Bar-On, 1996; Boyden, 1990; Burman, 1995; Hart, 2005; Lewis, 1998).

How do advocates see the CRC's norms relating to children in developing countries with very different experiences of childhood and addressing punishing childhoods? Children's rights advocates have challenged the belief that because human rights concepts historically come from Western societies they are not relevant to nonWestern societies. The historical origins of an idea do not prohibit its relevance for other societies, whether Arabic mathematics or Chinese fireworks (Donnelly, 2003, p. 71). Children's rights advocates believe human rights are universally applicable, and may be translated into different cultures, while being sympathetic to relativist understandings of culture which deny a hierarchy of cultures. Culture is regarded as a core resource for global advocacy, although the meaning of the term culture is used rather loosely. Culture is sometimes synonymous with a way of life or a people's identity, or sometimes refers more narrowly to symbolic communication. Global advocacy has picked up on anthropological and behavioural cultural models, which see cultural identity as necessary for a functional personality, while treating cultural norms as learned behaviour, which may be reformed through mobilising the CRC. The CRC's preamble states how the Convention takes 'due account of the importance of the traditions and cultural values of each people for the protection and harmonious development of the child'. Articles 8, 29, and 30 of the CRC recognise the preservation of identity and enjoyment of culture as rights. Subsequent documents like A World Fit for Children reiterate the importance of respecting cultural identity while condemning certain cultural practices (UN GA, 2002a, para 40(9)).

Advocates' understanding of culture's social construction follows the idealist strands of sociology and anthropology, which treat culture as distinct from social organisation, society as constructed through inter-subjectivity, and social change as the culmination of interpersonal change (Kuper, 1999). Thus one human rights advocate defines culture as consisting of 'fluid complexes of intersubjective meanings and practices' (Donnelly, 2003, p. 86). Contemporary advocacy departs from the functionalist approach to culture, which strongly influenced earlier twentieth century anthropology. Functionalism understands cultural norms and behaviour as having 
internal coherence: customs or practices, which may alarm outsiders, are functional within that community if analysed with appropriate cultural sensibility.

Global advocates' idea of cultural fluidity risks divorcing cultural norms from material conditions, and cultural transformation from material transformation. Historically Western social reform movements, including child advocacy, as compared to mass political movements, have emphasised moral or institutional reform and the role of professional interventions, and de-emphasised economic and social conditions (Boyden, 1990; King, 1997, pp. 7-8; Parton, 1985; Williams, 1963). UNICEF, in trying to understand the failures to realise children's rights, states:

Reasons range from weak political commitment and silent resistance by certain social groups with vested interests in discriminatory practices to the lack of institutional and administrative capacity and financial resources for implementing necessary reforms (UNICEF, 2000a, p. 10).

Even where resource problems are acknowledged here and elsewhere (UN CRC Committee, 2003, para 7), they are divorced from socio-economic relations of production. Conversely earlier international research considered a society based around household production fostered a soft state, whose ability to uphold the law impartially and secure a solid taxation basis for social services was undermined by weak productive capacity, a weak wage economy and the pressures of communal obligations (Galbraith, 1979, p. 11; Lipset, 1959, p. 66; Myrdal, 1956, 1957). So global advocacy emphasises the interdependence and indivisibility of political, social, and economic rights, but disregards the interdependence and indivisibility of political, social, and economic relations (Donnelly, 2003, pp. 27-33; UN CRC Committee, 2003, para 6; UNICEF, 2000a, p. 10). Logically, particular historical experiences encourage particular childhood norms, and shared historical experiences encourage norms to converge. This points to a problem in global advocacy seeking a 'progressive realization' of children's rights (UN CRC Committee, 2003, para 7), if the historical conditions, which fostered the childhood norms embodied in the CRC are not universally enjoyed. International development thinking, shared by children's rights advocates, imagines a different destiny for developing countries, involving substantial retention of traditional ways of rural survival and not following the historical development followed by Western societies (Duffield, 2007; Furedi, 1997; Pupavac, 2005).

The paradox of attempting to globalise post-industrial norms of childhood onto semiindustrial or non-industrial communities follow the recurring romantic critiques of modern society, which idealise childhood and a pre-industrial past (Sayre and Lowry, 1984). Significantly a cult of childhood developed in Western culture, which elevated childhood into a utopian space, upon which broader political hopes and fears were projected. The next section discusses the Western romantic concept of childhood and critique of modern industrial society, before illustrating the shifting cultural norms on punishing children.

\section{Western romantic concept of childhood}

The Western concept of childhood is bound up with the rise of capitalism, which broke up the feudal order and fostered individualism (Fromm, 1984; Riesman, 1950, 
Weber, 1954). Cultural ideas about childhood were shaped by Puritanism in the early capitalist period and by Romanticism in its later development. However Puritanism and Romanticism, although formally opposed, overlapped with each other, and other influences, over the last two centuries (Cox, 1996). Puritan thought avowed the spiritual character of family relations, and parents' responsibility for overcoming original sin and preparing their children for a worthy spiritual life. Stern discipline backed by corporal punishment was imperative to avert eternal damnation and the torment of hell's fires (ibid.). Conversely Romantic thought avowed elemental nature and challenged the idea of original sin. Romantic thinkers constructed childhood as being in special communication with nature. The poet William Wordsworth helped create the romantic cult of childhood and the ideal of the innocent child of nature in English-speaking culture (Wordsworth in Owens and Johnson, 1998, pp. 109-173). Romantic thought often represented adulthood as a fall from grace possessing a narrowed human sensibility and suggested that the child's proximity with the cleansing power of nature could teach adult society. If childhood was sacred and adulthood corrupt, then the child of nature needed to be preserved from corrupted adult, urban, industrial life to redeem humanity.

Romanticism's inverted roles, where the child redeems the adult, question adult discipline of children. The disciplined child is reconstructed as the damaged child. Romantic ideas appear in contemporary children's rights advocacy which suggests that if the world listens to children, it will be redeemed and realise peace, justice and economic security (UN GA, 2002a, para 50). This idea has become popular among international policy-makers who increasingly want consultative meetings with child delegates. So UN Secretary General Kofi Annan spoke of how 'we, the grown-ups, have failed you deplorably' at the UN General Assembly Special Session on Children in 2002 (UN GA, 2002b, p. 3). While Han Seung-soo, President of the Special Session, called upon delegates to 'set aside adult prejudices and listen to and learn from the children and young people who are with us' (ibid.).

Social constructivist approaches have distinguished the cultural ideal of childhood and the actual experience of childhood (Aries, 1962; Cox, 1996). The Romantic ideal child of nature was constructed against the background of early industrialisation's traumatic impact on communities and its harsh forms of child labour. Child labour was the norm in pre-industrial, predominantly agricultural communities, but became regarded as a problem under industrialisation's destruction of the traditional household economy. The Romantic cult of the natural child indicted industrialisation's oppression of the population. However the Romantic ideal intertwined with earlier puritan anxieties over moral corruption to pathologise urban working class children, when the earlier revolutionary Romantic sentiments gave way to social fears of the urban masses. Middle class moral reformism, driven by social fears was slow to address the conditions of the labouring classes, and improved children's lives in uneven, ambivalent ways, for example, criminalising street children or their families (Parton, 1985). Not least employment legislation was difficult to enforce where mass poverty necessitated children contributing to the family wage (Hindman, 2002; Marx, 1990; Tuttle, 1999; Gaskell, 1970, p. 129). Ultimately, child labour became redundant and children's lives were improved by overall improvements in family living standards and technological innovation, pushed by the successful organisation of the labouring classes. In summary, early industrial conditions created child labour as a problem, but child labour was eradicated as a 
mass social problem in advanced industrial conditions and successful labour organisation (Hindman, 2002, p. 8).

The idealised child of nature may be ambivalent for children in the developing world today, just as it was for children historically. Its mobilisation may not necessarily promote better understanding of their social conditions and the social solutions to transform their lives for the better. Notably child rural labour is naturalised and made invisible as a problem in the sustainable development model, which accepts nature's hard physical discipline over rural families, but not rural families' physical discipline of their children within the traditional household economy.

The following section illustrates how the cultural norms of punishing children progressively softened in Western societies during the modern era as children were excluded from labour responsibilities and childhood becoming a period of education and play.

\section{Disciplining childhood in the North American progressive era}

Discipline norms, like childhood norms in general, have a social history. Discipline over children has relaxed in advanced industrial societies only imposing minimal social responsibilities on children and lacking strong beliefs to instil in children. Children's rights advocates' suspicion of adult discipline over children reflects these developments, but overlooks the changing conditions of childhood in the advanced industrial countries, which allowed family discipline to soften. The history of childhood in North America during the Progressive Era of the late nineteenth and early twentieth century is instructive to understand how changing conditions of childhood in the advanced industrial countries allowed family discipline to relax. The national image as America-as-child or young uncorrupted America against old corrupted Europe makes discussion of children and social progress particularly close (Griswold, 1992, p. 62). Childhood norms changed rapidly, but unevenly, across social groups in this period of westward expansion and industrialisation. The huge rural and urban divide alongside social divides meant that very different childhood experiences and cultural norms coexisted within a generation or so. Discipline softened earlier among middle class families on the developed eastern coast of the United States whose children were not expected to work. Conversely the harsh conditions of pioneering farming communities dependent on child labour maintained severe family discipline and corporal punishment.

Changing cultural norms were expressed in children's classics of the period. The development of children's fiction was driven by the new interest in childhood and attracted social reformers championing more enlightened attitudes towards children. Children's fiction has often consciously promoted particular cultural values. Many children's novels, especially works for girls, were expressly commissioned by publishers to be morally edifying texts for families. They therefore reveal changing cultural expectations. Louisa Alcott's Little Women, Susan Coolridge's What Katy Did, Eleanor Porter's Pollyanna, Elizabeth Wetherall's The Wide Wide World, Laura Ingalls Wilder's Little House on the Prairie all fit into this genre. Moreover family discipline is a common theme in children's fiction, as Tom Sawyer's myriad scrapes and punishments testify (Twain, 2003). 
Alcott, author of Little Women, was brought up in a progressive, intellectual family, who disapproved of corporal punishment, anticipating contemporary children's rights thinking by over a century and a half. Discipline still included physical restraint and restraints, such as tying the disobedient Louisa to a chair, which would be condemned by child advocates today. However discipline was primarily through moral sanction and self-reflection towards self-sacrifice, codified in the children's diaries, which were rigorously analysed by their parents (Ebert, 1987, pp. 34-38). Little Women's disciplinary framework is John Bunyan's Pilgrim's Progress, but is gentler than the harsher puritan edicts of earlier children's works like Wetherall's The Wide Wide World. Little Women reproaches those who use corporal punishment, especially towards girls, and suggests that children should be 'governed by love' (Alcott, 1994, pp. 68-70). Nevertheless the disapproving Alcott distinguishes corporal punishment and violence, a distinction questioned in today children's rights advocacy, but common in earlier children's literature. Twain's writing, for example, sharply distinguishes violence and physical punishment, which he portrays as legitimate wellintentioned correction of misdemeanours. Huckleberry's father's drunken beatings are treated as violence, not simply because of their severity, but their irrational, unpredictable and ill-intended nature (Twain, 1983).

Alcott's disapproval of corporal punishment in the 1860s contrasts with Laura Wilder's endorsement in her Little House series, set in the 1870s-1880s and written five decades later. Wilder's writing testifies to the tough, precarious lives of pioneer families. Strict family discipline, whether children's absolute obedience to their parents or the discipline of religious and cultural standards and routines, is portrayed as imperative for their survival in the hostile environment and ability to combat demoralisation when disasters strike (Wilder, 1953). Moreover without the family disciplining itself for a future beyond subsistence farming, it is clear how the demands of the household economy could easily lead to children's education becoming abandoned. Wilder morally affirms corporal punishment and reproaches parents for not punishing disobedient children as irresponsibly endangering lives and futures (Wilder, 2000a, p. 120; 2000b, pp. 92-93). Corporal punishment as morally good is symbolised by Laura's father spanking her on her birthday:

today was her birthday, and she would not grow properly next year unless she had a spanking.... One spank for each year, and at the last one big spank to grow up (ibid., pp. 54-55).

Fiction showed fate punishing the disobedient, even without parental punishment. Katy in Coolidge's What Katy Did pays for disobeying and playing on a dangerous swing with a serious back injury, from which she does not recover until she has learnt humility, self-discipline and other virtues.

Children's fiction indicates how discipline softened culturally, where life was easier. Some children were released from economic responsibilities in the American south through the use of slaves - anti-slavery is a core theme in Twain's Huckleberry Finn. Children's household responsibilities diminish to the odd chores in Twain's Tom Sawyer, imposed more for moral instruction than necessity. Aunt Polly's dilemmas over disciplining Tom Sawyer capture the related changing cultural views on discipline: 
I ain't doing my duty be that boy, and that's the Lord's truth, goodness knows. Spare the rod and spoil the child, as the Good Book says. I'm alaying up sin and suffering for us both, I know. [...] Everytime I let him off, my conscience does hurt me so, and everytime I hit him my old heart most breaks (Twain, 2003, p. 11).

Tom's beloved aunt still uses corporal punishment but her views are ambivalent. Tom is not intimidated by her half-hearted efforts, 'She never licks anybody - whacks 'em over the head with her thimble, and who cares for that, I'd like to know' (ibid., p. 21). Tom treats discipline as competitive sport where children try to outwit adults and escape punishment. The lively comic cat and mouse game between adults and children conveys the sense of an optimistic dynamic period in American history where traditional relations were being overturned, inequitable institutions like slavery questioned, and people lived by their wits. The tensions over discipline in Tom Sawyer do not concern corporal punishment so much as the restrictions of domestication. The boys' trials echo the romantic elemental child of nature and illustrate how children might construct their schema of childhood's rights and wrongs rather differently from adult champions of their welfare!

If Twain's America was still wild and only partially tamed, later moral tales like Pollyanna (Porter, 1969) or Anne of Green Gables (Montgomery, 1994) reflect a more secure, comfortable, North American provincial life, where the need for child labour was being superseded. The cultural paramountcy of duty was shifting to happiness. Fictional representations of disobedience were transformed from wickedness to naughtiness and discipline softened. Disobedient protagonists, unlike earlier figures, were no longer forced to wait for recovery in long chapters of repentance (Montgomery, 1994). Children's disregard for adult rules in this new generation of fiction was even portrayed positively. Symbolically Pollyanna's impertinence is represented as a generous spontaneous spirit reinvigorating the lives of those around her, counter-posed to cold adult reserve (Porter, 1969). Progressive novels like Pollyanna invert the relationship between adults and children, making the child the main protagonist of social change. Many works are rather cloying for today's tastes, but children's rights advocacy repeats their romance: the child of nature saving adult society and spontaneous social change as a chain reaction of personal change.

Alcott, for example, was attracted to the romantic identification with nature against the ills of contemporary society. Alcott's family circle included her father Bronson Alcott, Henry Thoreau and Ralph Emerson, writers whose ideas embodied the recurring Western romantic reactions against industrial society and anticipate the contemporary ideals of sustainable development (Elbert, 1987, chapter 4). But Alcott was sceptical about a return to nature. Her Transcendental Wild Oats satirises her father's failed utopian Fruitlands farming experiment as Slump Apples. The work wryly observes women and children labouring for the community while the idealist male leaders are off lecturing about their wonderful community in comfortable city salons. She did not discount material needs and rejected her father's anti-materialism, for all the nobility she saw in his stance (Elbert, 1987, p. 221). Furthermore Alcott believed industrialisation and waged labour opened up possibilities for individuals denied them in the household economy, notwithstanding exploitative working conditions which she attacked (ibid., pp. 103-104; p. 165). 
Wilder's Little House series creates a romance of small independent family farming, and celebrates the family's spiritual values and simple pleasures. Nevertheless the Little House's improved material security depended on wage labour and is far from being anti-materialist, quite the reverse (Romines, 1997, pp. 97-137). Material things matter in the Little House, whether the practical value and reliable quality of new machine goods, which lighten their labour or culturally enhance their lives. Not least Wilder's writing career only became possible through the availability of the sewing machine and industrially-made cloth which freed up women and girls' labour in the household (ibid.). In summary the chronology of these Progressive Era works suggest how rising standards of living and widening social experiences fostered progressive values, greater social opportunities and made possible childhood as a period of play and education in Western societies.

The rest of this article explores tensions between the universalism of human rights advocacy and the relativism of economic development.

\section{Urban pathologies and romantic critiques of universal economic development}

International development was established after 1945 in a political climate of heightened post-colonial expectation and Cold War competition to address the aspirations of the newly independent states to be industrialised and raise living standards. The most urgent problem was rural poverty, because family health, education, labour and opportunities were considered worse in rural than urban areas (Black, 1996, p. 119; UNICEF, 1963, 1964). A green revolution would transform rural labour through applying scientific knowledge and modern machinery to enhance crop yields. Optimistically, it was hoped economic modernisation and urbanisation would modernise cultural norms, and encourage cultural and political values to converge internationally, thereby helping to overcome international divisions and further international peace (Rostow, 1960). However newly independent countries experienced capital flight and had difficulty securing capital investment unless they were of strategic interest.

Moreover Western governments and advisers were ambivalent about industrialising the Third World. They feared modernisation was destabilising traditional societies and politically alienating populations as people migrated from rural areas to growing urban slums (Huntington, 1968; Lerner, 1967, p. 28; Mead, 1953; Pye and Verba, 1965; Weiner, 1966). International policy advisers were concerned urbanisation exacerbated social problems and that parents struggled to mediate children's experience of traumatic social change (Inkeles, 1963, p. 365). Urban poverty became regarded as more harmful than rural poverty to the young (Black, 1996, p. 129), although studies continued to suggest that urban migration offered poor families the chance of upward mobility not available in rural areas (Nelson, 1969). Early optimism diminished that many urban problems were transitional. Fears grew that urban life eroded family ties and left the young without appropriate parental guidance (Black, 1996, pp. 128-130). The presence of street children suggested modernisation strategies were endangering social community and welfare (ibid.). Shanty towns and urban slums were creating maladjusted young people at risk of delinquency: 
social disorganization leads to the family's failure to ensure that the personality of young people develops satisfactorily, since, lacking the requisite norms, they are apt to indulge in all kinds of anti-social behaviour (Hauser, 1961, p. 54).

Against these fears, Western governments and advisers retreated from the goal of industrialising the developing world. Their ideas influenced international development thinking as Third World nationalism and mass political movements sympathetic to Third World nationalism declined.

International development thinking converged around the concept of sustainable development and basic needs, outlined in E.F. Schumacher's Small is Beautiful (1973), the Brandt Report (1980) and other initiatives, which proposed that developing countries should not follow Western industrial development paths. Sustainable development approaches reaffirm Western romantic critiques of modernity, which look back to nature and non-industrial communities as the ideal (Sayre and Lowry, 1984). Just as the romantic imagination thinking approached childhood as a utopian space in communication with nature, which must be kept free adult urban corruption, sustainable development advocacy commonly imagines the developing world as a non-materialist space at risk from modern society's corruption. Indeed many Western development thinkers and aid workers like Schumacher have been like drawn to international development work as part of a personal spiritual journey wanting to refocus society onto spiritual well-being against materialism.

Sustainable development advocacy rarely acknowledges developing countries' hostility towards abandoning industrialisation as a goal - developing countries reiterated their aspirations for international economic equality and industrialization in the 1974 UN Declaration on the New International Economic Order (UN, 1974). Influential international development critiques were originally inspired by Marxist ideas against capitalist modernisation models, regarded as furthering Western interests at the expense of developing countries (Frank, 1971; Samir, 1976). Anticolonial nationalists like the Algerian writer Frantz Fanon argued against the Third World following Western models, but did not mean adopting pre-industrial relativist development models: 'there is not a question of a return to Nature' (Fanon, 2008, p. 82). Fanon wanted the Third World to transform and forge a new universal historical project:

No, we do not want to catch up with anyone. What we want to do is to go forward all the time, night and day, in the company of Man, in the company of all men ... It is a question of the Third World starting a new history of Man...(Fanon, 2008, p. 82).

Third world nationalism was influenced by universalist beliefs, whereas sustainable development advocacy is influenced by cultural relativism, questioning economic modernisation strategies which it holds responsible for much suffering in the developing world (Rahanema and Bawtree, 1997). Its non-materialist relativist development model tends to gloss over common negative aspects of traditional agricultural societies - their conservative gendered cultural norms and divisions of labour, child labour and use of corporal punishment - or treats disturbing cultural 
practices as superfluous to traditional ways of life and therefore eradicable because particular cultural practices are not found in all traditional communities.

\section{Structural adjustment and children's rights development}

Universal development was abandoned in the 1970s, but the movement to universalise human rights revived. There is not the space here to consider the international political context that fostered renewed international attention to human rights (Evans, 1996, 1998; Sellars, 2002). UNICEF had originally been unenthusiastic about the initiative to create a new children's rights convention. UNICEF changed its views, hoping a children's rights approach might prioritise children's welfare and mitigate the effects of the 1980s' debt crisis and structural adjustment programmes (Black, 1996). UNICEF devised selective low-cost interventions that would impact most on child survival, while UNICEF's Children in Extremely Difficult Circumstances programme targeted interventions towards groups at risk (Black, 1996, p. 18-21; Cornea, Jolly, and Stewart, 1987). The selective interventions pioneered by UNICEF improved child survival rates and represented sensible crisis management strategies. However the 'adjustment with a human face' measures have become the essential meaning of material development today, which is focused on better-targeted allocation of social resources as opposed to transforming society's productive industrial base as a foundation for social progress. Today's rights-based, human development or sustainable development approaches are sceptical about economic growth strategies. Fulfilment of basic needs is their material goal, not universal prosperity (UNICEF, 2000a).

International development advocacy is increasingly focused on changing norms rather than material advancement as the way of improving society. The General Assembly's A World Fit for Children contends, 'Investing in children and respecting their rights lays the foundation for a just society, a strong economy, and a world free of poverty' (UN GA, 2002a, para 50). Similarly UNICEF argues 'The well-being of children is a key yardstick for measuring national development' (UNICEF, 2000b, p. 1). Nevertheless children's prospects are still largely determined by whether they come from advanced industrial countries or developing countries, and their country's wealth and their families' income. UNICEF's Progress for Children Statistical Review shows that the Sub-Saharan Africa has either made no progress or insufficient progress towards realising Millennium Development Goals on infant mortality, hunger, access to safe drinking water and basic sanitation and schooling (UNICEF, 2007). But international children's rights reports treat their goals of protecting children's health and well-being as achievable (UN GA, 2002a, para 48). Advocates emphasise the better allocation and access to basic services for children's well-being, rather than a country's position in the international political economy and its productive capacity (UNICEF, 2007). Yet China's economic growth strategies have succeeded in getting more adults and children out of poverty than international child poverty strategies (Chen and Ravallion, 2008, p. 20). International children's rights advocates do not address how the available resources and means of allocation in societies organised around basic technological household production, as opposed to advanced industrial production, are qualitatively different and inevitably entail different standards of children's health and well-being. Children's rights advocacy has retreated from the comprehensive development vision of sixty years ago. Not least, its rights-based development vision does not aspire to universal access to technologically advanced 
medical care, and offers children in the developing countries lower health prospects than Truman's vision of sixty years ago, which aspired to universalise the benefits of science and technology to all globally.

Yet today's international advocates want to transcend older material definitions of poverty and material income-based indicators (UNICEF, 2000a). Even the World Bank has come under the influence of anti-materialist thinking. Its report The Voices of the Poor (Narayan et al, 2000) does not have substantial material transformation as part of its development vision and even suggests that wealth and well-being may be incompatible (Duffield, 2007; Pender, 2002, 2007; Pupavac, 2005). Multidimensional models of poverty are promoted as more advanced analysis than the older material models of poverty (UNICEF, 2000; Narayan et al, 2000). Their policy adoption is redefining poverty in more psychological terms and resurrecting the cycles of poverty models, associated with conservative moral reformers. UNICEF argues 'Poverty causes lifelong damage to children's minds and bodies, transforming them into adults who perpetuate the cycle of poverty, by transmitting it to their children' (UNICEF, $2000 \mathrm{a}, \mathrm{p} . \mathrm{v}$ ) and that 'the intergenerational transmission of poverty cannot be broken unless children's basic capabilities and skills are developed from birth' (ibid., p. 6). The human development approach involves development strategies directed towards the individual: training individuals to realise their own livelihoods, as opposed to the macro industrial employment schemes of the past (ibid., p. 9).

The present normative approaches targeted at the poor or children as development actors repackage self-help strategies, and offer little material advancement (Abrahamsen, 2000). They follow how moral reformers historically have seen social solutions in terms of professional interventions at the level of the individual. Even today's basic needs approaches offer individuals less materially and are increasingly targeted towards changing the poor's attitudes and behaviour. Basic material provision is more selective designed to impact on general population survival rates (Duffield, 2007), and contradicts the CRC, which purports to address the rights of every individual child globally. This contradiction is accompanied by other contradictions in global children's rights advocacy.

\section{Idealist constructions of punishing childhoods}

A fundamental paradox exists in global children's rights advocacy seeking to globalise the childhood norms of post-industrial societies without globalising the material conditions of childhood, which fostered those norms. The 1990 African Charter proclaims that children are to be protected from 'economic exploitation' and 'performing any work that is likely to be hazardous or to interfere with the child's physical, mental, spiritual, moral, or social development' (Article 15). Children's worst prospects are in the poorest region of the world - Sub-Saharan Africa. UNICEF's own statistics suggest that one in three children aged five-fourteen are engaged in child labour in Sub-Saharan Africa, compared to one in six of the world's children (UNICEF, 2007, p. 45).

The children's rights-based approach does not address how the mode of production in developing countries under the sustainable development vision will be predominantly agrarian based on small-scale family farming without advanced machinery. Setting aside romantic rural images, family farming without modern machinery involves 
intensive toil requiring child labour. UNICEF's Progress for Children report highlights 'poor and rural children are more likely to be engaged in child labour' (UNICEF, 2000b, p. 45). This picture is presented starkly in Kindernothilfe NGO report on Africa, extracted here:

In Ethiopia [...] practically every second boy works [...]. Almost 95 percent of working children are to be found in rural areas. Over 92 percent are unpaid helpers within their families, who pursue economic activities. Almost 68 percent of working children and young people work in small (agricultural) family businesses. Working in informal family enterprises can expose children and young people to serious violations of their rights as shown by the fact that over 47 percent of five to nine year old boys and almost 35 percent of girls work 40 plus hours a week. Added to that in the southern part of the country a share of the children are bonded child labourers (Heidel, 2005, p. 18).

UNICEF and international NGOs document child labour in the unmechanised rural economy, yet do not fundamentally question sustainable development's implications for children. Fifty years ago UNICEF wanted to eradicate the relentless toil of traditional unmechanised rural economies as a foundation for improving people's lives (Black, 1996, p. 119). Conversely the children's rights framework approaches the traditional rural economy's hardships as problems of legal enforcement and changing cultural behaviour, rather than material necessity. The Kindernothilfe report refers to the long hours that rural children labour as seriously violating their rights. But would rights enforcement address the social conditions that require rural children and their families to labour long hours? UNICEF and international NGOs have adopted a blinkered development agenda, which somehow imagines unmechanised agricultural work without hours of toil. But family farmsteads rely on children working, as Wilder's Little House testifies.

Previous policy saw cultural change as premised on breaking away from traditional ways of life. Past modernisation studies on developing countries emphasised that family discipline softened as a traditional way of life shifted to a modern way of life and individualism. These trends were strongest amongst the urban middle classes most integrated into modern society and the most industrialised nations (LeVine et al, 1967, p. 223). Yet the historical experiences, which fostered the gentler norms that advocates wish to enforce, are not shared globally. Effectively, global children's rights advocacy aims to globalise post-industrial professional norms of childhood discipline onto non-industrial conditions. But discipline norms are part of a totality of social relations. Traditional farming necessitates children disciplined to labour because household survival depends on everybody, including children, fulfilling their allotted responsibilities. The tough conditions of traditional agriculture are a hard physical discipline over both adults and children and its high stakes make for tough discipline norms. Global advocacy disingenuously condemns people to a tough way of life and then condemns their tough discipline norms, as if they are superfluous to the physically onerous tasks demanded of children. However, global advocates, predominantly urban and middle class, are less alarmed about the hazards of rural life than urban life, haunted by the romantic child of nature intertwined with older puritan moral anxieties. As Alcott wryly observed over a century ago, idealists may happily lecture on the joys of simple living comfortably insulated from its insecurities and hardships (Alcott, 1975). 
Sustainable development's tacit perpetuation of child labour needs more study, although insightful analysis exists on the global political economy's impact on children and global advocacy's ambivalence for children (Boyden, 1994; Lewis, 1998; Hart, 2005; King, 1996; Niewenhuys, 2000, 2001; Watson, 2006). Human rights debates over universalism or relativism have focused on Asian values, but have not fundamentally addressed whether universal human rights are realisable under relativist development policies. It is difficult to find human rights literature asking whether universal human rights require modern social conditions, as was previously presumed. Rarely Donnelly suggests that traditional communal forms of life have to be broken to realise equal rights, but does not follow through the problem of how rights may be realised where development policy seeks to maintain traditional communal forms of life (Donnelly, 2003, p. 76). Instead uneven development is seen as making human rights imperative rather than unrealisable (ibid., p. 85). Nor does the prevailing idealist philosophy of human rights follow through the contradictions of the international political economy that undermine individuals' rights, highlighted by earlier underdevelopment theories (Frank, 1970; Samir, 1976). Prevailing children's rights approaches are losing historical understanding of social change and increasingly confuse the expanding role of children's rights advocates with addressing children's plight globally. Indicatively the Kindernothilfe report does not refer to the development of developing countries, but the development of the PRSPs, and children's rights organisations' participation in their formulation (Heidel, 2005).

To what extent can adult interactions with children be changed while retaining traditional economic organisation around family labour? Past international policy assumed that people's social conditions needed to be materially eased for progressive cultural norms to flourish, and that social norms changed more slowly than economic and technological practices (Mead, 1966, p. 54). For childhood norms to change, the underlying material social conditions need to be substantially transformed. Present campaigns to prohibit corporal punishment effectively sever the link between social conditions and cultural norms. Advocates seek to use culture flexibly, maintaining those traditional cultural features they like, while eradicating those features they disapprove and deem unnecessary to cultural identity, like harsh corporal punishment. But can culture be treated in a pick ' $n$ ' mix way? The insecurities of traditional rural farming communities, struggling against nature, foster cultural conservativism. They rely on trusted traditional ways and kinship support networks, because they cannot rely on external welfare (Galbraith, 1964, 1979; Mead, 1953, pp. 185-6). Earlier development studies showed how public education programmes impacted little on traditional communities unless they saw their children's social possibilities expanding (Mead, 1953, 1966). Public education programmes within Western countries also appear to have poor results where social mobility has slowed or reversed (Hardeman et al, 2002). International development thinking of fifty years ago aspired to transform social possibilities along with comprehensive universal public welfare services. Conversely global advocacy wants to mobilise traditional communities to change core family norms and relations according to the CRC, while they depend on traditional livelihoods and kinship networks for their material security. But when global advocacy disturbs existing patterns of interdependencies and responsibilities, it risks making children's lives more insecure where new sources of external welfare are absent (Mead, 1953, 1966). Global children's rights advocates are sensitive about accommodating existing cultural beliefs, but tend to affirm cultural self-determination 
narrowly around symbolic rituals, folklore, or craftwork, distinct from social practices. Inevitably global advocacy disturbs communities' social and economic expectations when it invites communities to compare their adult-child relations against global children's rights norms. Simultaneously it implicitly invites people to make other global comparisons with people in developed countries, even though global development advocacy seeks local development paths (Laidi, 1998). So while global advocates formally promote a basic needs development model of local selfreliant communities, their very appearance communicates messages of cosmopolitan mobility and affluence.

The old moral divisions between the deserving and undeserving, and between the civilised and the uncivilised, are also re-appearing in children's rights discourse, albeit in contemporary language.

\section{Pollyanna advocacy delegitimising the developing world}

Global advocacy over punishing childhoods in the developing world questions the international legitimacy of developing states because it constructs populations' problems divorced from the prevailing material conditions. International relativist development and rights-based approaches, not just earlier development models, are susceptible to criticisms of reproducing unequal relationships and reproducing 'endlessly the separation between reformers and those to be reformed' (Escobar, 1997, p. 93). Global children's rights campaigns claim moral legitimacy against developing societies by isolating physical punishment from the harsh physical conditions of the developing world. Children's rights advocacy moralises the gap between the ideal of childhood under the CRC and the reality of many children's lives globally, rendering their societies in violation of their rights. As a consequence, developing countries are morally delegitimised as representatives of their children's best interests and become sites of extensive intervention under evolving relationships of global governance between the North and the South (Lewis, 1998). Child rights advocates are demanding that developing countries institutionalise their normative analysis of global problems and solutions. They want European governments and institutions to enforce child rights in PRSPs, and Western NGO evaluations to be incorporated into the international reviews of PRSPs (Heidel, 2005; UN CRC Committee, 2003, para 12). Simultaneously tacit international racial divisions are recreated in global children rights advocacy against developing societies for their failure to ensure their children live up to the romantic ideal of childhood (Lewis, 1998, p. 97).

Aspirations to make children's lives better cannot be isolated from our aspirations for humanity as a whole. The normative universalism and material relativism of global children's rights advocacy are at odds, and legitimise the perpetuation of gruelling social conditions. The prevailing sustainable development policies maintain punishing childhoods dictated by the necessity of nature. Current social constructivist interpretations of childhood have flown from reality. Selective normative campaigns lacking historical understanding divert the development of analysis and action essential to forge a more humane world. There is something very Pollyanna-ish about children's rights advocacy: people's nastiness to each other is so unnecessary, if only people could be nice to each other, if only adults could stop being horrible and hitting their children, then peace and harmony could be released through innocent children. 
Seeking to enforce post-industrial cultural norms in developing societies, without intending to transform the material conditions of childhood substantially, is perverse, and only reinforces international inequalities. Progressive thinking and practice, to transform the lives of children and address punishing childhoods globally, needs to reassert the interdependence between material progress and social progress.

\section{Bibliography}

Abrahamsen, Rita (2000) Disciplining Democracy: Development Discourse and Good Governance in Africa. London: Zed Books.

Alcott, Louisa (1994) Little Women. London: Penguin.

Alcott, Louisa (1975) Transcendental Wild Oats. Boston, Mass.: Harvard Common Press.

Amin, Samir (1976) Unequal Development. Hassocks: Harvester Press.

Ariès, Philippe (1962) Centuries of childhood. London: Cape.

Bar-On, Arnon (1996) 'Criminalising Survival: Images and Reality of Street Children', Journal of Social Policy, Vol. 26, No. 1, pp 63-78.

Benedict, Ruth (1961) Patterns of Culture. London: Routledge.

Black, Maggie (1996) Children First: The Story of UNICEF. Oxford: Oxford University Press.

Boyden, Jo (1990) 'Childhood and the Policy Makers: A Comparative Perspective on the Globalization of Childhood', in Allison James and Alan Prout (eds) Constructing and Reconstructing Childhood. London: Falmer Press, pp 184-215.

Brandt Commission or Independent Commission on International Development Issues (1980) North-South: A Programme for Survival. London: Pan Books.

Van Bueren, Geraldine (1995) The International Law on the Rights of the Child. Martinus Nijhoff, Dordrecht.

Burman, Erica (1995) 'Developing Differences: childhood and economic development.' Children \& Society, Vol. 9, No. 3, pp. 121-141.

Chen, Shaohua and Martin Ravallion (2008) The Developing World Is Poorer Than We Thought, But No Less Successful in the Fight against Poverty. Policy Research Working Paper 4703. The World Bank Development Research Group.

Cornia, Giovanni Andrea; Richard Jolly, and Frances Stewart (1987) Adjustment with a Human Face. Oxford: Oxford University Press.

Cox, Roger (1996) Shaping Childhood: Themes of Uncertainty in the History of Adult-Child relationships. London: Routledge. 
Cunningham, Hugh (1995) Children and Childhood in Western Society since 1500.

London: Longman.

Detrick, Sharon (ed) (1992) The United Nations Convention on the Rights of the Child: A Guide to the "Travaux Preparatoires". Dordrecht: Martinus Nijhoff.

Donnelly, Jack (2003) Universal Human Rights in Theory and Practice. Ithaca, NY: Cornell University Press, second edition.

Duffield, Mark (2007) Development, Security and Unending War: Governing the World of Peoples. Cambridge: Polity.

Elbert, Sarah (1987) A Hunger for Home: Louisa May Alcott's Place in American Culture. New Brunswick and London: Rutgers University Press.

Evans, Tony (1996) US Hegemony and the Project of Universal Human Rights. Basingstoke: Macmillan Press.

Evans, Tony (ed.) (1998) Human Rights Fifty Years On: A Reappraisal. Manchester: Manchester University Press.

Fanon, Frantz (2008) Concerning Violence. London: Penguin.

Federle, Katherine (1994) 'Rights Flow Downhill.' International Journal of Children's Rights, Vol. 2, pp. 343-368.

Frank, Andre Gunder (1971) Capitalism and Underdevelopment in Latin America. Harmondsworth: Penguin.

Freeman, Michael (1997) The Moral Status of Children: Essays on the Rights of the Child. The Hague: Martinus Nijhoff.

Fromm, Erich (1984) The Fear of Freedom. London: Ark.

Furedi, Frank (1997) Population and Development: A Critical Introduction. Cambridge: Polity.

Galbraith, J.K. (1964) Economic Development. Cambridge, MA: Harvard University Press.

Galbraith, J.K. (1979) The Nature of Mass Poverty. Cambridge, MA and London: Harvard University Press.

Gaskell, Elizabeth (1970). Mary Barton. Harmondsworth: Penguin.

Global Initiative to End All Corporal Punishment of Children http://www.endcorporalpunishment.org/ 
Griswold, Jerry (1992) Audacious Kids: Coming of Age in America's Classic Books. New York: Oxford University Press.

Hardeman, W. et al (2002) 'Application of the Theory of Planned Behaviour Change Interventions: a Systematic Review.' Psychology and Health, Vol. 17, pp. 123-158.

Heidel, Klaus (2005) Poverty Reduction Strategy Papers: Children first! A case study on PRSP processes in Ethiopia, Kenya and Zambia from a Child Rights Perspective. Heidelberg: Kindernothilfe. http://www.sarpn.org.za/documents/d0002048/PRSP_Children-first_Sept2005.pdf

Hindman, Hugh (2002) Child Labor: An American History. Armonk: M.E. Sharpe.

Huntington, Samuel (1968) Political Order in Changing Societies. New Haven, Conn: Yale University Press.

King, Michael (1997) A Better World for Children? London Routledge.

King, Michael and Judith Trowell (1992) Children's Welfare and the Law: The Limits of Legal Intervention. London: Sage Publications.

Lewis, Norman (1998) 'Human Rights, Law and Democracy in an Unfree World', in Tony Evans (ed.) Human Rights Fifty Years on: $a$ reappraisal. Manchester: Manchester University Press, pp. 77-104.

Lipset, Seymour Martin (1959) Political Man. London: Mercury.

Marx, Karl (1990) Capital: A Critique of Political Economy. Volume One. London: Penguin.

Mead, Margaret (ed.) (1953) Cultural Patterns and Technical Change. Paris: Unesco with the World Federation for Mental Health.

Mead, Margaret (1956) New Lives for Old: Cultural Transformation - Manus, 19281953. New York: Mentor Books.

Mead, Margaret (1966) Culture, Health and Disease: Social and Cultural Influence on Health Programmes in Developing Countries. London: Tavistock.

Mead, Margaret and Wolfenstein (1955) Childhood in Contemporary Cultures. Chicago: Chicago University Press.

Mill, John Stuart (1985) On Liberty. London: Penguin.

Montgomery, Lucy (1994) Anne of Green Gables. London: Puffin.

Myrdal, Gunnar (1956) An International Economy. New York: Harper \& Bros.

Myrdal, Gunnar (1957) Economic Theory and the Under-Developed Regions.

London: Duckworth. 
Narayan, Deepa with Raj Patel, K. Schafft, Anne Radenmacher and Sarah KochSchulte (2000) Voices of the Poor: Can Anyone Hear Us? Oxford: Oxford University Press.

Nieuwenhuys, Olga (1998) 'Global Childhood and the Politics of Contempt.' Alternatives, Vol. 23, pp. 267-289.

Nieuwenhuys, Olga (1999) 'The Paradox of the Competent Child and the Global Childhood Agenda', in R. Fardon, W. van Binsbergen and R. van Dijk (eds) Modernity on a Shoestring, Dimensions of Globalisation, Consumption and Development in Africa and Beyond. Leiden and London: EIDOS, pp 33-48.

Nieuwenhuys, Olga (2000) 'The Household Economy and the Commercial Exploitation of Children's Work, The Case of Kerala', in B. Schlemmer (ed.) The Exploited Child. London and New York: Zed Books, pp. 278-291.

Nieuwenhuys, Olga (2001) 'By the sweat of their brow? Street children, NGOs and children's rights in Addis Ababa.' Africa Vol. 71(4):539-557.

O’Neill, Onora (1992) 'Children's Rights and Children's Lives', in P. Alston, S. Parker and J. Seymour (eds) Children, Rights and the Law. Oxford: Clarendon Press, pp. 24-42.

Organisation of African Unity (1990) African Charter on the Rights and Welfare of the Child, OAU, Doc. CAB/LEG/24.9/49 (1990), entered into force Nov. 29, 1999.

Owens, W.R. and Hamish Johnson (1998) Romantic Writings: An Anthology. Milton Keynes: Open University.

Parton, Nigel (1985) The Politics of Child Abuse. Basingstoke: Macmillan.

Pender, John (2002) 'Relegitimising Intervention: The World Bank and the Voices of the Poor', in D. Chandler (ed.) Rethinking Human Rights: Critical Approaches to International Politics, pp. 97-114. Basingstoke: Palgrave.

Pender, J. (2007) 'Country Ownership: the evasion of donor accountability', in Christopher Bickerton, Philip Cunliffe and Alexander Gourevitich (eds) Politics without Sovereignty: A Critique of Contemporary International Relations. London: Routledge, pp. 112-130.

Porter, Eleanor (1969) Pollyanna. Harmondsworth: Penguin.

Pupavac, Vanessa (2011 forthcoming) 'War-Affected children, International Crisis of Meaning, and the Limits of Rehabilitation Programmes', in Wouter Vandenhole (ed.) Rehabilitation and Reintegration of Children Affected by War. Antwerp: Intersentia Publishers.

Pupavac, Vanessa (2005) 'Human Security and the Rise of Global Therapeutic Governance.' Conflict, Security and Development, Vol. 5 (2), pp. 161-181. 
Pupavac, Vanessa (2002) 'The International Children's Rights Regime', in David Chandler (ed.) Rethinking Human Rights: Critical Approaches to International Politics. Basingstoke: Palgrave, pp. 57-75.

Pupavac, Vanessa (2001) 'Misanthropy without Borders: The International Children's Rights Regime.’ Disasters, Vol. 25, No. 2, pp. 95-115.

Pye, Lucian W. and Sidney Verba (eds) (1965) Political Culture and Political Development. Princeton: Princeton University Press.

Romines, Ann (1997) Constructing the Little House: Gender, Culture, and Laura Ingalls Wilder. Amherst: University of Massachusetts Press.

Rostow, W. W. (1960) The Stages of Economic Growth: a Non-Communist Manifesto. London: Cambridge University Press.

Sayre, Robert and Michael Lowy (1984) 'Figures of Romantic Anti-Capitalism.' New German Critique, No. 32, pp. 42-92.

Schofield, Kevin (2007) 'Smacking vital as last resort, insist parents in "Growing Up" study.' Scotsman, 20 January.

Schumacher, E.F. (1973) Small is Beautiful: A Study of Economics as if People Matter. London: Blond \& Briggs.

Sellars, Kirsten (2002) The Rise and Rise of Human Rights. London: Sutton Publishing.

Sen, Amartya (1975) Employment, Technology and Development. Oxford: Clarendon.

Sen, Amartya (1999) Development as Freedom. Oxford: Oxford University Press.

Tuttle, Carolyn (1999) Hard at Work in Factories and Mines: The Economics of Child Labor during the British Industrial Revolution. Oxford: Westview.

Twain, Mark (1983) The Adventures of Huckleberry Finn. London: Penguin.

Twain, Mark (2003) The Adventures of Tom Sawyer. Bath: Parragon.

UN Committee on the Rights of the Child (UN CRC) (2003) General Measures of Implementation for the Convention on the Rights of the Child, General Comment No. 5. Geneva. CRC/GC/2003/5

UN CRC (2006a) General Comment No. 8 on the right of the child to protection from corporal punishment and other cruel or degrading forms of punishment (CRC/C/GC/8).

UN CRC (2006b) Benin Concluding observations on second report CRC/C/BEN/CO/2, 20 October. 
UN General Assembly (1974) Declaration on the Establishment of a New Economic Order, General Assembly Resolution 3201 (S-V1), 1 May 1974

UN General Assembly (1989) UN Convention on the Rights of the Child, General Assembly Resolution 44/25 20 November 1989, Entry into force 2 September 1990. http://www.ohchr.org/english/law/pdf/crc.pdf

UN General Assembly (2002a) A World Fit for Children. General Assembly Resolution A/RES/S-27/2 http://www.unicef.org/worldfitforchildren/files/A-RESS27-2E.pdf

UN General Assembly (2002b) Twenty-Seventh Special Session on Children. General Assembly A/S-27/PV.1

UN Millennium Development Goals. Available at web site: http://www.un.org/millenniumgoals/

UN Secretary General (2001) We the Children: End-decade review of the follow-up to the World Summit for Children. New York: United Nations.

http://www.unicef.org/specialsession/documentation/documents/a-s-27-3e.doc

UN Secretary General (2006) Secretary General Study on Violence against Children. New York: United Nations. http://www.violencestudy.org/r25

UNICEF (1963) The Needs of Children. New York: The Free Press of Glencoe.

UNICEF (1964) Children of the Developing Countries. London: William Clowes.

UNICEF (1999) Children in Jeopardy: The Challenge of Freeing Poor Nations from the Shackles of Debt. New York: UNICEF.

UNICEF (2000a) Poverty Reduction Begins with Children. New York: UNICEF

UNICEF (2000b) Progress of Nations 2000. Geneva: UNICEF. http://www.unicef.org/pon00/

UNICEF (2005) 'Call to ban corporal punishment wraps up South Africa meeting on violence.' http://www.unicef.org/media/media_27721.html

UNICEF (2007a) Progress for Children: A World Fit for Children Statistical Review. New York: UNICEF.

UNICEF (2007b) State of the World's Children. Geneva: UNICEF. http://www.unicef.org/sowc07/docs/sowc07.pdf

Verhellen, Eugene (1997) Convention on the Rights of the Child. Leuven: Garant.

Watson, Ali (2006) 'Children and International Relations: A New Site of Knowledge?' Review of International Studies, Vol. 32, Number 2, pp. 237-250. 
Weber, Max (1954) Max Weber on Law in Economy and Society. New York: Simon \& Schuster.

Weiner, Myron (ed.) (1966) Modernization: The Dynamics of Growth. Washington DC: Voice of America Forum Lectures.

Wetherall, Elizabeth (1950) The Wide Wide World. London: University of London.

Wilder, Laura Ingalls (1953) The Long Winter. New York: HarperCollins.

Wilder, Laura Ingalls (2000a) Little House in the Big Woods. London: Egmont.

Wilder, Laura Ingalls (2000b) Little House on the Prairie. London: Egmont.

Williams, Raymond (1963) Culture and Society 1789-1950. Harmondsworth: Penguin. 